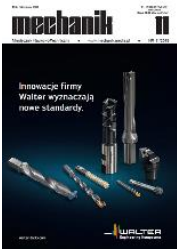

How to cite this article:

Authors: Paweł Bałon, Adam Kochman, Edward Rejman, Bartłomiej Kiełbasa, Robert Smusz, Adam Burek, Janusz Szostak, Łukasz Kowalski, Andrzej Świątoniowski

Title of article: "Research and FEM analysis of the injection pump shaft for diesel engines"

Mechanik, No. 11 (2019)

DOI: https://doi.org/10.17814/mechanik.2019.11.94

\title{
Research and FEM analysis of the injection pump shaft for diesel engines
}

\author{
PAWEL BAŁON \\ ADAM KOCHMAN \\ EDWARD REJMAN \\ BARTŁOMIEJ KIEŁBASA \\ ROBERT SMUSZ
}

\author{
ADAM BUREK \\ JANUSZ SZOSTAK \\ ŁUKASZ KOWALSKI \\ ANDRZEJ ŚWIĄTONIOWSKI *
}

\footnotetext{
* Dr inż. Paweł Bałon, balonpawel@gmail.com, https://orcid.org/0000-0003-3136-7908 - Zakład Produkcyjno-Usługowy Mirosław Pogoda, Mielec, Polska; Akademia Górniczo-Hutnicza w Krakowie, Kraków, Polska

Mgr inż. Adam Kochman, biuro@pogoda.mielec.pl, https://orcid.org/0000-0001-7899-1439 - Zakład Produkcyjno-Usługowy Mirosław Pogoda, Mielec, Polska

Dr inż. Edward Rejman, edwardrejman@o2.pl, https://orcid.org/0000-0003-4716-7613 - Zakład Produkcyjno-Usługowy Mirosław Pogoda, Mielec, Polska

Mgr inż. Bartłomiej Kiełbasa, b.kielbasa@pogoda.mielec.pl, https://orcid.org/0000-0002-3116-2251 - Zakład Produkcyjno-Usługowy Mirosław Pogoda, Mielec, Polska

Dr hab. inż. Robert Smusz, robsmusz@gmail.com, https://orcid.org/0000-0001-7369-1162 - Zakład Produkcyjno-Usługowy Mirosław Pogoda, Mielec, Polska

Inż. Adam Burek, a.burek@pogoda.mielec.pl, https://orcid.org/0000-0003-1915-6366 - Zakład Produkcyjno-Usługowy Mirosław Pogoda, Mielec, Polska

Dr inż. Janusz Szostak, szostak@.agh.edu.pl, https://orcid.org/0000-0002-7789-3383 - Akademia Górniczo-Hutnicza w Krakowie, Kraków, Polska

Mgr inż. Łukasz Kowalski, lkowalski@agh.edu.pl, https://orcid.org/0000-0002-2866-9000 - Akademia Górniczo-Hutnicza w Krakowie, Kraków, Polska

Prof. dr hab. inż. Andrzej Świątoniowski, https://orcid.org/0000-0003-4832-3418 - Państwowa Wyższa Szkoła Zawodowa im. Stanisława Pigonia w Krośnie, Krosno, Polska
}

The paper presents the methodology for designing the drive shaft of the injection pump for diesel engines with cylinder numbers of $2,3,4,6$ and power from $2,5 \mathrm{~kW}$ to $52 \mathrm{~kW}$ per cylinder using the finite element method (FEM) and experimental research. The pump is the original solution of the authors. The shaft is the basic part of the pump with a complex structure. In order to assess the state of stress in the shaft, the analytical FEM was used and experimental tests were carried out, subjecting the shaft to twisting with the design torque resulting from the transferred power. Experimental research confirmed the results of numerical calculations and the correctness of the adopted solution. In order to evaluate the maximum load capacity of the shaft, destructive tests were carried out, charging it with increasing torque until visible plastic deformations occurred. This condition occurred at a time twice as high as the maximum anticipated moment in operation.

KEYWORDS: shaft, injection pump, diesel engine, FEM

\section{Introduction}

Injection pumps used in Poland for diesel engines of agricultural tractors and working machines as well as for special uses especially in the military are currently not equipped with production facilities (the companies, that do so, has liquidated and machines, devices and production equipment - were scrapped). Due to the low 
intensity of exploitation of this machines group (and very high purchase costs of new ones) would be operational for the next several dozens of years. In order to provide continuity of their operation and at the same time allow improving of diesel engines operating parameters in those machines there is ongoing work on development of new injection pump for two, three, four, six and eight-cylinder engines with power from 7,5 kW to $57 \mathrm{~kW}$ per cylinder, which can work with the maximum discharge pressure on the pump side up to $150 \mathrm{MPa}$ $[8,9]$. For the purposes of usability and functionality assessment for a new type of pomp, a pomp prototype was developed and it was a subject of experimental research. Own experience in designing, results of experimental researches and assessment of pomp durability on the basis of multi-annual repairs of these devices indicate that one of their critical components is drive shaft. This component operates in tough conditions and is exposed to variable torque values. This affects the way of shaft damage, which has fatigue character. The presence of this type of pump defects during operation cause significant damages (damage a lot of critical pomp structural components).

\section{Own solutions}

Machines elements design requires from constructors to meet many requirements, including ensuring appropriate constructional, technological and operational characteristics. The adopted solution assumes that pump driven shaft will have two parts: proper shaft and shrink connected ring controlling rotor pistons, moving pistons giving fuel. Because of the existing shaft loading and its manufacturing technology was used tempered C25 steel up to hardness approx. HB 250. The adopted pump construction solution has forced the shaft elements introduction, which will be the cause of stress concentration and the same potential source of fatigue fractures. That places are straight slots with a width of $10 \mathrm{~mm}$ and length of $20 \mathrm{~mm}$ and appearing in its area ring notch of diameters 25 and $28 \mathrm{~mm}$. From the point of view of stress concentration this fragment was evaluated as potential damage section.

For preliminary shaft design were used stress formulas for the cross-section shown in fig. 1. It was assumed that shaft is loaded by a maximum torque $M_{\mathrm{s}}=300 \mathrm{Nm}$, applied to input part conical surfaces and uniformly distributed. For this load condition maximum tangential stresses reach the value $\tau_{\max }=105,1 \mathrm{MPa}$.

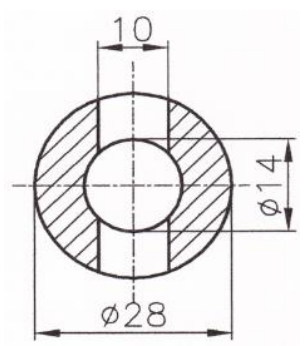

Fig. 1. Critical section of the injection pump drive shaft

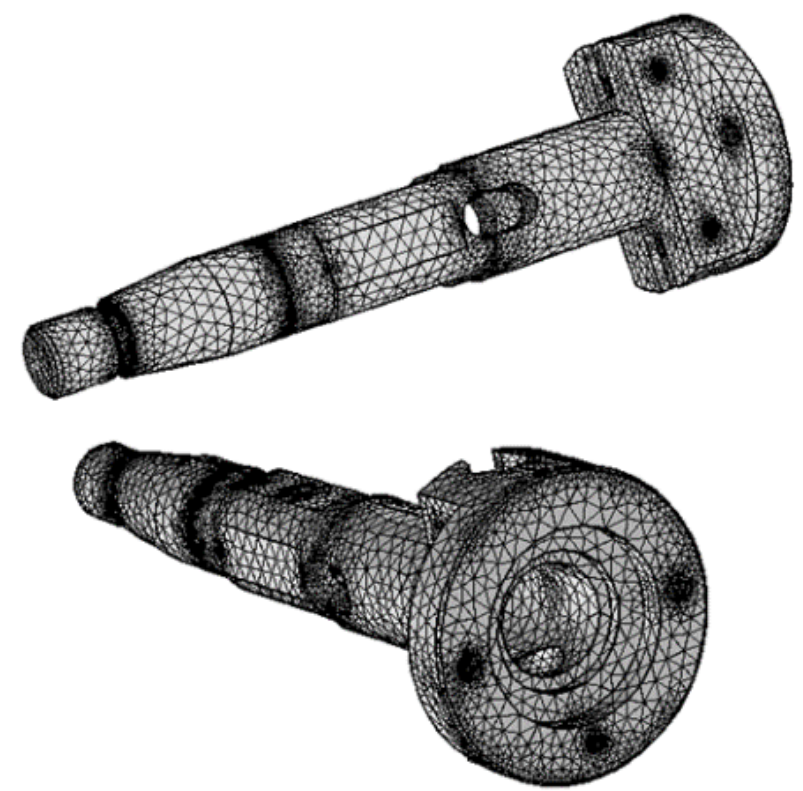

Fig. 2. FEM mesh model used in the designed shaft 


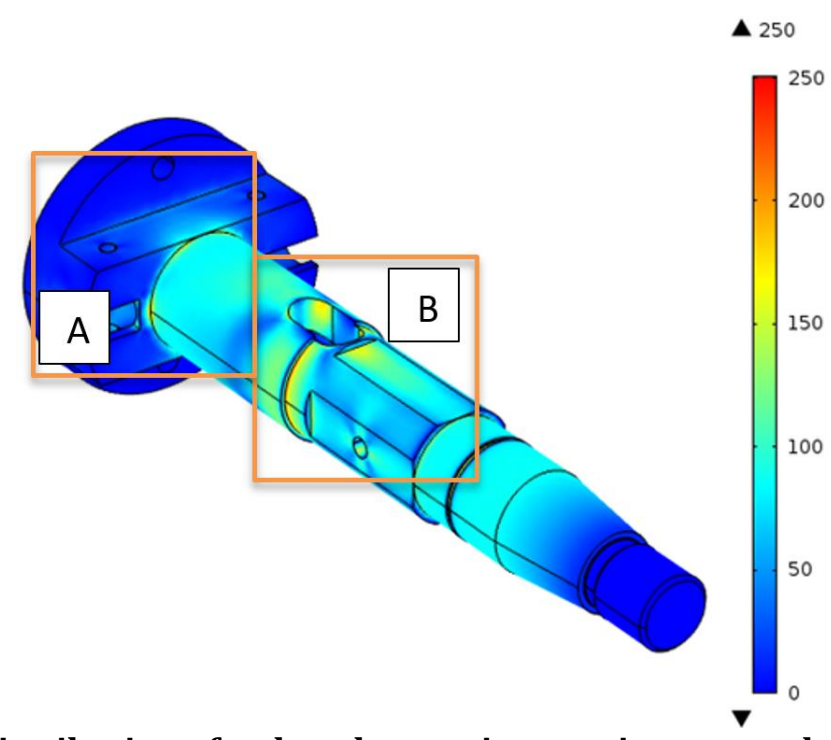

Fig. 3. Distribution of reduced stress in a torsion pump shaft [MPa]

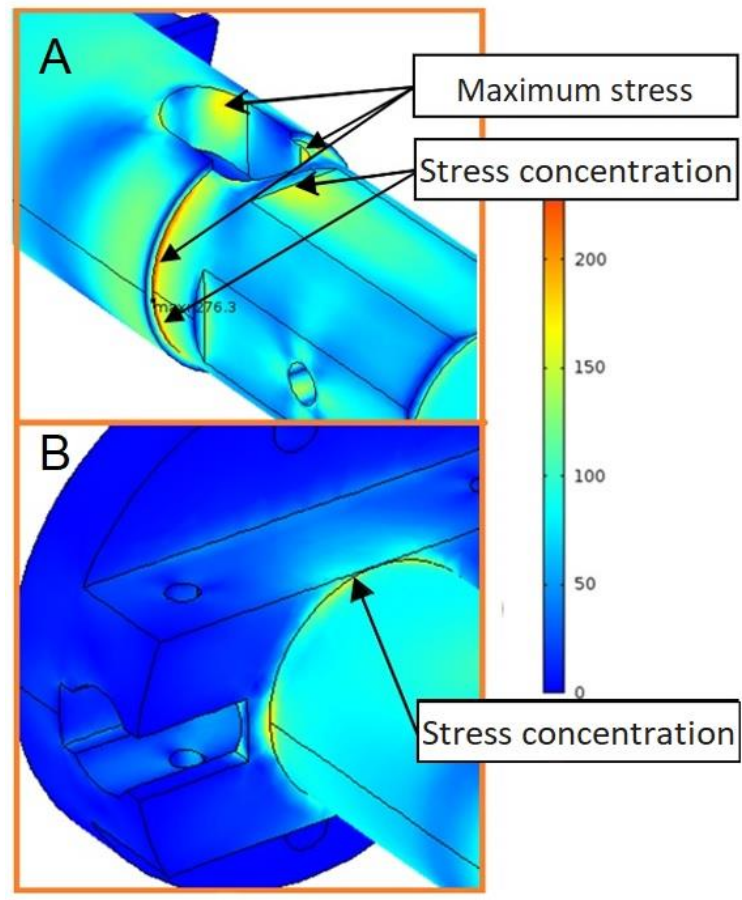

Fig. 4. Zones of the largest stress concentration in the pump shaft [MPa]

Multiple notches occurring in designed construction are an unusual solution and it's difficult to find such case in the literature describing in analytic or graphic way local stress concentration $[4,5]$. It is worth pointing out that those notches have interacted with each another [3].

Analytical tests have been carried using the finite element method in order to estimate stress concentration in critical shaft points. Shaft 3D model has been developed, shaft is loaded by torque $M_{\mathrm{s}}=300 \mathrm{Nm}$, uniformly applied to input part conical surfaces and uniformly distributed and applied to conical surfaces (fig. 2). Linear elastic material model was assumed, with material Young Modulus $E=200 \mathrm{GPa}$, Poisson's ratio $v=0,33$ and yield strength $R_{\mathrm{e}}=320 \mathrm{MPa}$ (steel C25). Stress was determined in accordance with Huber-Mises-Hencky hypothesis (HMH). Tetrahedral finite element mesh of tetra type was used in discrete model (fig. 2).

The results of the calculations are shown in fig. 3-5.

In fig. 3 is shown global distribution of stress reduced in the shaft. It can be noted two zones - A and B where there is high stress concentration linked to introduction of significant geometrical notches, as shown in fig. 4. On this basis it can be concluded that maximum stress appear in zone B - in further research emphasis is placed on this construction detail. The analysis of fig. 4 indicates that the highest stress will occur in groove and shafts transition cross-section from diameter 28 to $25 \mathrm{~mm}$ and pass radius $R=0,2 \mathrm{~mm}$ (zone B in fig. 3 ) - stress 
reduced $\sigma_{\text {red }}$ reach respectively $180 \mathrm{MPa}$ and 276,3 MPa (maximum stress reduced in the shaft are shown in fig. 5), so safety coefficient refer to material yield strength $x_{\mathrm{p}}$ have values 1,77 and 1,17 . From the fatigue fractures standpoint the second case is especially dangerous, where fractures initiation might occur $[1,2]$. In order to reduce concentration at the point of diameter transition, edge rounding by radius $R=1 \mathrm{~mm}$ and $R=2 \mathrm{~mm}$ was implemented. This has resulted in decrease of stress reduced respectively to level $219 \mathrm{MPa}$ and $188 \mathrm{MPa}$ and increase of final safety coefficient up to 1,7 .
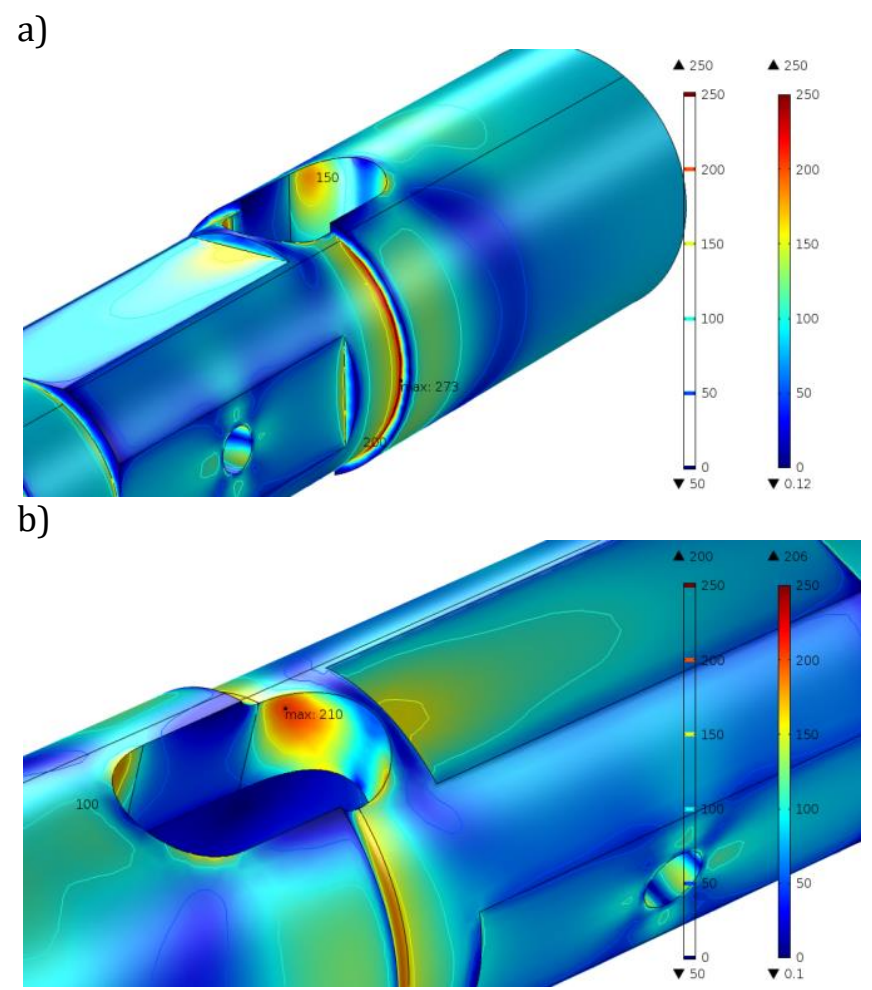

Fig. 5. Maximum stress reduced in the shaft

\section{Experimental research}

In order to verify the results of the theoretical research was made shaft experimental research. They include an assessment of the shaft resistance under static torque (fig.6).

The shaft 3 is mounted on rolling bearings and is attached to the ground 4 by one end. Torque, which load on shaft is transmitted by coupling 2 . This torque is generated by force $F$ acting in arm $L$ on the intermediate shaft 1 , which couplings absorb transverse load. This solution protects the shaft against bending moment and lateral forces. The studies were carried out, changing force $F$, and therefore also torque $M_{\mathrm{s}}$. For expected values of practical shaft load $M_{s}=300 \mathrm{Nm}$, the shaft did not show any permanent deformations - after relieving the load, the shaft was returned to the initial position. In order to evaluate the shaft load capacity, moment value was increased until signs of plastic deformation. Visible, permanent plastic deformations have occurred at load moment $M_{\mathrm{s}}=602 \mathrm{Nm}$. According to theoretical calculations, this state corresponds to reduced stress equal to material yield strength - approx. $325 \mathrm{MPa}$. Given the function of the shaft in injection pump, then it can be considered destroyed. The place of yield point shown in fig. 7.

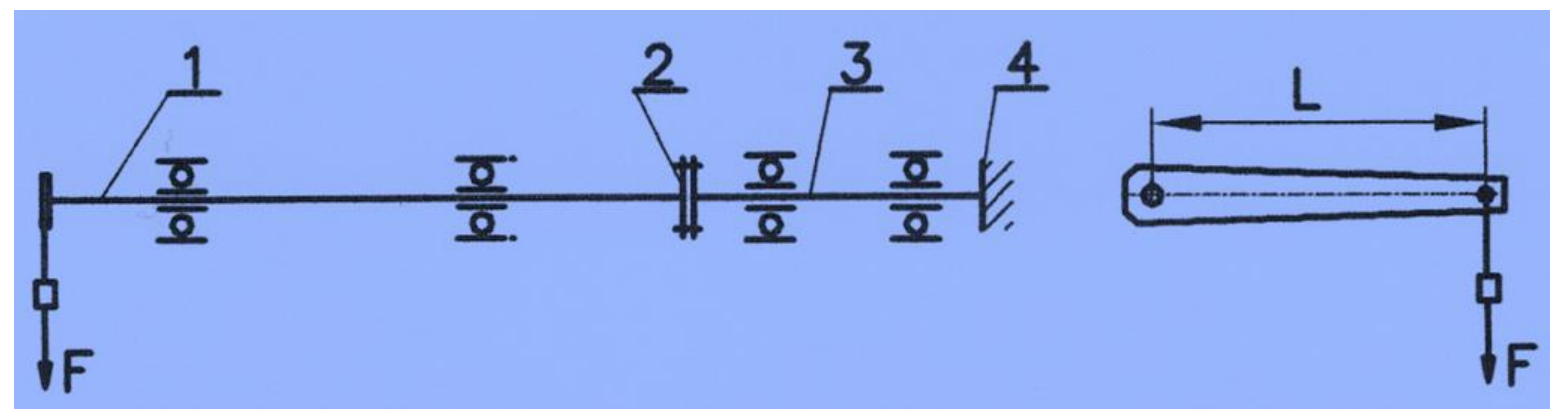

Fig. 6. Stand for testing the pump shaft for torsion (operation diagram) 


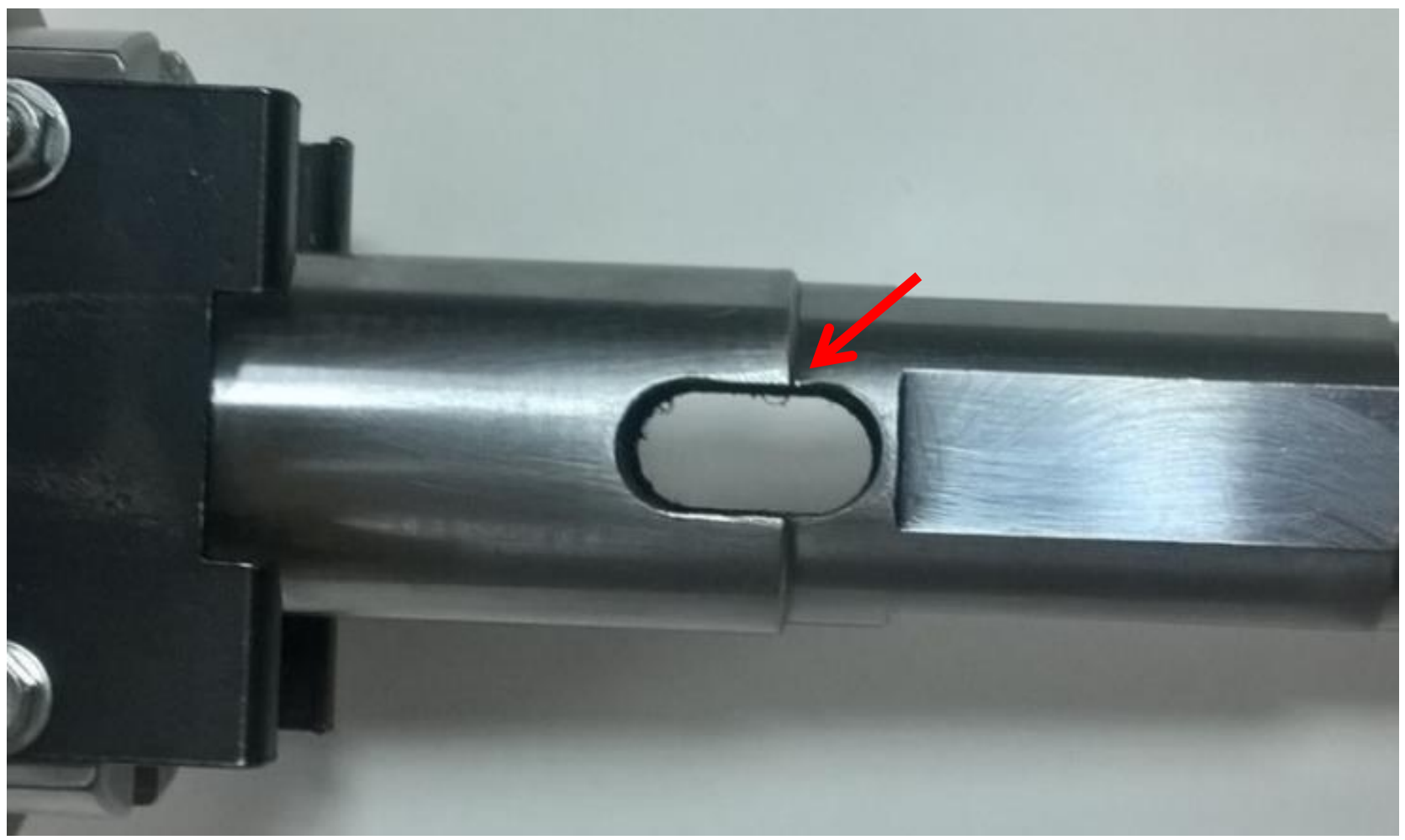

Fig. 7. Place of the greatest stress concentration in the pump shaft with plastic deformations

\section{Conclusions}

The injection pump drive shaft is one of its basic elements. On correct functioning of the pump and ensuring appropriate fuel-injection phases decide shaft resistance and its torsional stiffness.

The complexity of the structure of entire unit enforces appropriate shape of the elements, including shaft. In the present case have been introduced - due to functional reasons - an unusual solution, including pass-through slot representing significant structural noche not published in literature about shafts. The case studies have confirmed very clear stress concentration (coefficient $\alpha_{\mathrm{k}}$ at a level 2,63, and according [5] - even 4,7), which may have been the cause of fatigue fractures.

Carrying-out operations consisting mainly in acceptable ( for design reasons) transition radius modifications of individual shaft stages made possible to preserve appropriate structure resistance representing by actual safety factor at the level of $x_{\mathrm{p}}=1,7$, which should be considered permissible.

Shaft experimental tests confirmed correctness of calculation model and construction solution. Structure damage takes place for the torque value $M_{\mathrm{s}}=602 \mathrm{Nm}$, so more than doubled to maximum torque value transmitted by pump shaft in extreme operating environments.

\section{REFERENCES}

[1] Kocańda S. „Zmęczeniowe pękanie metali”. Warszawa: WNT, 1985.

[2] Kocańda S., Szala. „Podstawy obliczeń zmęczeniowych”. Warszawa: PWN, 1985.

[3] Lisowski F. „Modelowanie MES struktur o karbach szeregowych”. Czasopismo Techniczne. 7 (2011): 341-348.

[4] Peterson R.E. "Stress conventraction factors". New York: Willey 1974.

[5] Pilkey W.D. Pilkey D.F. "Petersons's stress concentration factors". John Willey \& Sons, Inc., 2008.

[6] Serensen S.V., Kogaev V.P., Snejderovic R.M. "Nesuscaja sposobnost i rascety detalej masin na procnost”. Moskva: Masinostroenie, 1975.

[7] Wilson W.K. "Stress intensity factors for deep cracks in bending and compact tension specimens". Engineering Fracture Mechanics. 2 (1970).

[8] Praca zbiorowa. "Układy wtryskowe Unit Injector System i Unit Pump System". Warszawa: WNT, 2011.

[9] Kasedorf J. "Zasilanie wtryskowe olejem napędowym". Warszawa: Wydawnictwo Komunikacji i Łączności, 1990. 